\title{
A research of the attitudes of sports sciences students towards disabled people
}

\author{
Gul CAVUSOGLU, Saban UNVER, Izzet ISLAMOGLU, Yucel MAKARACI
}

Yasar Dogu Faculty of Sport Sciences, Ondokuz Mayls University, Samsun, Turkey.

Address Correspondence to G. Cavusoglu, gulcavusoglum@hotmail.com

\begin{abstract}
The purpose of this study was to determine the attitudes of students who had a class on disabled people and those who did not. The students who participated in the study were studying at the Faculty of Sports Sciences of Ondokuz Mayis University during the academic year 2013-2014. Disabled people generally encounter negative attitudes. Despite all the precautions taken, being disabled is perceived as an "excluded, unaccepted and despised" concept. This behavior causes a negative attitude towards disabled people. The students' attitudes towards disabled people were analyzed in terms of demographic features. 203 (57 female and 146 male) students studying at Ondokuz Mayıs University, Yaşar Doğu Faculty of Sports Sciences participated in the study. The data was collected through a "Demographic Information Form" developed by the researcher and "Attitude Scale for Disabled People" developed by Prime Ministry Department of the Administration of the Disabled. The level of significance for all statistical procedures was taken as 0.05 . All the statistical analyses were made through SPSS package program. The total average score taken by the students on Attitude Scale for Disabled People was 170.93 ( $\mathrm{n}=203$, Min: 122, Max:207, SD:20.18). A significant difference was found between the attitude score means of students who took classes about disabled people and those who did not, in terms of gender $(p<0.01)$. The results of the study showed that the students who took lessons about disabled people had positive attitude towards disabled people. The effect of gender on the attitude towards disabled people is a result which is consistent with the literature. Thus, perceptions of the society towards disabled people should change, administrative and legal precautions should be taken to prevent the exclusion of disabled people and their families from the society and societal responsibilities should be fulfilled.
\end{abstract}

Keywords: Attitude, disability, university student.

\section{INTRODUCTION}

Social life requires people to show attitudes and behaviors within the frame of certain rules. Thus, a person needs to relate to his/her environment in order to be able to adapt to the environment (23). Decisions we make as a result of our attitudes that affect our relations and our behaviors are based on our assessments. These attitudes, decisions and actions show our perspectives and tendencies (8). Attitudes are learned as a result of experiences and they are influenced by the values the parents have (15). Being influenced and influencing causes a person to influence his/her social environment or to be influenced by his/her social environment as a result of the relationship and interaction built with this environment. Thus, it can be understood that a person has the power to influence and change as well as being influenced by the environment he/she lives in. This aspect of a person can sometimes cause a person to experience some events that can affect his/her life to a great extent. Although reasons such as accidents, illnesses or acting insensibly are effective in the occurrence of these events, sometimes innate genetic disorders and hereditary disorders come to the forefront. Disabilities that occur as a result of illnesses, accidents or innate genetic influences are defined in different ways (10). World Health Organization defines these concepts as the following: impairment is a shortcoming or anomaly in a person's physiological, psychological, anatomical structure or functions. Disability is a lack or restriction of ability to perform an activity that a normal person can successfully do and occurs as a result of impairment. Disabilities can be temporary (malnutrition, infectious diseases), permanent (blindness, mental retardation) or progressive (degenerative illnesses, heart disease). Handicap is a disadvantage for a given individual that limits or prevents the fulfillment of a function that is normal for that individual and it occurs as a result of a disability or impairment depending on age, gender, social and cultural activities (24). An individual who 
has lost physical, mental, spiritual, emotional and social abilities in various degrees as a result of an innate or acquired illness or accident and who cannot meet the necessities of a normal life is defined as "impaired" (9).

If handicapped individuals are thought as humans before their handicaps, attitudes towards them will be positive (15). Some of the serious obstacles that prevent handicapped people from participating in the society effectively as equal citizens are known to be caused by people's discriminative behaviors against handicapped people. Studies on discriminative behavior towards handicapped people have focused on social universes where closer, more intense or more permanent relationships such as the ones in family and immediate surroundings, work environment and school environment are experienced (13).

In their study Chan et al. found that students of rehabilitation department showed more positive attitudes when compared with the students of economy (3). The most important reason for this difference is education. Increased levels of education, trainings on handicapped people and creating positive relationships with handicapped people develop positive attitude towards handicapped people (4).

The purpose of this study is to determine the attitudes of students studying at Ondokuz Mayis University Faculty of Sports Sciences and taking the course "physical training and sports for handicapped people" and the students studying at the same department but not taking any lessons on handicapped people and to present this information to the knowledge of people in this field.

\section{MATERIAL \& METHOD}

203 students studying at Ondokuz Mayis University Faculty of Sports Sciences participated in the study voluntarily. After the students were informed about the purpose of the study, questionnaires were administered to students in classes in their free time by the researchers during the 2013-2014 Academic Year Fall Semester. The students were explained that the data of this study would be used for scientific purposes and their answers would remain anonymous. The questionnaire was administered in about 15 minutes.

The data of the study was collected through a "demographic information form" developed by the researchers and "attitude scale towards handicapped people" developed by the Prime Ministry department of the administration of the disabled (2008) (21). Demographic information form included information about the students' "age, gender, taking the course about handicapped people and presence of a handicapped person in the family". Attitude scale towards handicapped people contains 43 questions.

The data was analyzed through SPSS 19.0 package program and Kolmogorov Smirnov test was used to check whether the data showed normal distribution and it was found that some of the data did not show normal distribution. Mann Whitney U test was used to find the differences between two groups. $T$ test was administered on data that showed normal distribution. Level of significance was 0.05 .

\section{RESULTS}

In Table 1, in the comparison of attitude scores towards handicapped people in terms of whether courses on handicapped people were taken, significant difference was found between students who took this course and who did not.

When Table 2 was reviewed, significant difference was found between the comparisons of attitude scores towards handicapped people in terms of gender.

Table 1. Comparison of attitude scores towards handicapped people in terms of whether courses on handicapped people were taken.

\begin{tabular}{cccccccc}
\hline Whether courses on handicapped people were taken & $\mathrm{N}$ & Mean & SD & Median & Min. & Max. & P \\
\hline & & & & & & & \\
Yes & 101 & 175.95 & 19.26 & 181.00 & 126.00 & 207.00 \\
No & 102 & 166.19 & 20.29 & 169.50 & 122.00 & 209.00 & 0.000 \\
Total & 203 & 171.04 & 20.33 & 174.00 & 122.00 & 209.00 &
\end{tabular}


Table 2. Attitude scores towards handicapped people in terms of gender.

\begin{tabular}{ccccccccc}
\hline Gender & $\mathrm{N}$ & Mean & SD & Median & Min. & Max. & $\mathrm{t}$ & $\mathrm{P}$ \\
\hline Female & 57 & 179.19 & 19.58 & 183.00 & 126.00 & 209.00 & & \\
Male & 146 & 167.86 & 19.79 & 169.50 & 122.00 & 207.00 & 3.67 & 0.000 \\
Total & 203 & 171.04 & 20.33 & 174.00 & 122.00 & 209.00 & & \\
\hline
\end{tabular}

Table 3. Attitude scores towards handicapped people in terms of presence of handicapped people in family.

\begin{tabular}{cccccccc}
\hline $\begin{array}{c}\text { Presence of handicapped people in } \\
\text { family }\end{array}$ & $\mathrm{N}$ & Mean & Std. Dev. & Median & Min. & Max. & P \\
\hline Yes & & & & & & & \\
No & 10 & 170.70 & 18.12 & 169.50 & 146.00 & 205.00 \\
Total & 193 & 171.06 & 20.48 & 174.00 & 122.00 & 209.00 & 0.829 \\
& 203 & 171.04 & 20.33 & 174.00 & 122.00 & 209.00 \\
\hline
\end{tabular}

Table 4. Attitude scores towards handicapped people in terms of age.

\begin{tabular}{cccccccc}
\hline Age Groups & $\mathrm{N}$ & Mean & Std. Dev. & Median & Min. & Max. & P \\
\hline 20-23 age & 121 & 171.24 & 20.83 & 171.00 & 122.00 & 209.00 \\
24-27 age & 82 & 170.75 & 19.69 & 173.00 & 125.00 & 207.00 & 0.759 \\
Total & 203 & 171.04 & 20.33 & 174.00 & 122.00 & 209.00 & \\
\hline
\end{tabular}

In Table 3, no significant difference was found in the comparison of attitude scores towards handicapped people in terms of presence of handicapped people in family.

When Table 4 was reviewed, no significant difference was found in the comparison of attitude scores towards handicapped people in terms of age groups

\section{DISCUSSION}

Taking courses on handicapped people is an important factor in developing attitudes towards handicapped people. Sufficient backup education towards handicapped people is important in making students form positive attitudes. The purpose of this study was to determine the attitudes of Ondokuz Mayis University Faculty of Sports Sciences students who took courses about the handicapped and who did not towards the handicapped. In the study, total average ASTHP (Attitude Scale towards Handicapped People) score of students who took courses about the handicapped was 176 (Min: 126, Max: 207, Std.Dev: 19.26). This score shows that students have positive attitudes towards handicapped people. Total average ASTHP score of students who did not take courses about the handicapped was 166 (Min: 122, Max: 209, Std. Dev: 20.29). This score can also be considered normal; however, it can be seen that it is a lower score when compared with the students who took the courses.
There are studies reporting university students have intermediate levels of attitudes towards the handicapped $(6,14)$. This finding proves the effect of education on attitudes towards the handicapped.

Krahe \& Altwasser (2006) reported that negative attitudes towards the handicapped could be changed through programs integrated into the school environment. In their study that they conducted with this purpose, they found a positive change in individuals who interacted with the handicapped (7). These findings are in parallel with the results of our study. When the attitude scores towards the handicapped were compared based on courses about the handicapped, a significant difference was found between the students who took these courses and who did not. Şahin \& Güldenoğlu implemented a 60-hour educational program that lasted for 12 weeks, compared the attitudes towards the handicapped before and after the program and found similar results to our study (19).

In our study, a significant difference was found when attitude scores were compared in terms of gender that was thought as a factor that could affect attitudes towards the handicapped. When the literature was reviewed; similar to our study results, a significant difference was found between the attitude scores of the students of nursing department based on their genders and the average scores of female students were found to be higher 
than those of male students (17). Tervo et al. also found that medicine students who were male had more positive attitudes than female students (22).

No significant difference was found between groups in terms of having a handicapped among relatives or friends. Horner- Johnson et al. stated that students who had handicapped individuals among relatives or friends were more sensitive to the rights of the handicapped while Şenel found that having a handicapped sibling did not affect attitudes $(6,20)$. The results of our study are in parallel with the results of other researchers. No significant difference was found in the comparison of the attitude scores of students in terms of having a handicapped in their family.

In the comparison of attitude scores based on age groups which is thought to be another factor that could affect attitudes towards the handicapped, no significant difference was found. When the literature of different age groups (16) and parents (12) towards the handicapped. Unlike our findings, there are also studies that found differences between age groups $(5,1,2,11,18)$. It can be thought that the inconsistency in the findings related to age is caused by the differences in the age ranges of the samples in studies.

As a result of the findings of the study, a significant difference was found between the attitude scores of students who took the course "Physical Training and Sport for Handicapped" and those of the students who did not. As a result, it should be remembered that in order to make the attitudes towards handicapped people around us more positive, it is important for every individual in society to show effort for the psychological and social developments of the handicapped. Educational studies can be made to create positive changes in the attitudes of university students. Within this context, it is thought that students will show positive behaviors towards these individuals with the help of aforementioned courses.

\section{REFERENCES}

1. Atay M. A Study on the Attitudes of Teachers towards Inclusive Programs in which Disabled Children Study with their Normal Peers. Unpublished Doctoral thesis, Hacettepe University, Ankara, 1995.

2. Avcıoğlu H, Sazak-Pınar E, Öztürk T. Analysis of the Attitudes of Parents and Teachers towards Inclusive Programs in Preschool Educational Institutions. XIV. National Special Education Congress Proceedings, 2005; 69-89.

3. Chan $\mathrm{CCH}$, Lee TMC, Yuen HK and Chan F. Attitudes toward People with Disabilities Between Chinese
Rehabilitation and Business Students: An Implication for Practice. Rehabilitation Psychology, 2002; 47: 324-38.

4. Daruwalla P, Darcy S. Personal and Societal Attitudes to Disability. Annals of Tourism Research, 2005; 32: 549-70.

5. Gülderen N. Analysis of the Attitudes of Parents who have Normal Children towards Deaf Children. Unpublished Master thesis, Abant İzzet Baysal University, Bolu, 1997.

6. Horner-Johnson W, Keys C, Henry D, Yamaki K, Oi F, Watanabe K, Shimada H, et al. Attitudes of Japanese students toward people with intellectual disability. Journal of Intellectual Disability Research, 2002; 46: 365-78.

7. Krahe B, Altwasser C. Changing Negative Attitudes towards Persons with Physical Disabilities: An Experimental Intervention. J. Community Appl. Soc. Psychol, 2006; 16: 5969.

8. Kuçuradi Dİ. The Problem of Value in terms of Human Philosophy. Ankara: Yankı Publications, 1971.

9. Kula MN. Being Physically Handicapped and Dealing with it Religiously, Dem Publications, İstanbul, 2005.

10. Kula N. Model of Muhammad the Prophet in the Lives of Handicapped People and their Families (Çorum model). Journal of Science of religion Academic Research, 2009; 11(1): 164.

11. Küçüker S, Kanık-Richter N. Attitudes of Parents who have Normal Children towards Disabled Children. Journal of Special Education, 1994; 1 (4): 20-28.

12. Küçükturan G. Determination of the Attitudes of Mothers whose Children Need Special Education. Unpublished Master thesis, Hacettepe University, Ankara, 1982.

13. Mark CW. Disability Harassment. NYU Press, New York, 2007.

14. Nagata KK. The measurement of the Hong Kong-based 'Baseline Survey of Students' Attitudes toward People with a Disability': crosscultural validation in Lebanon. International Journal of Rehabilitation Research, 2007; 30: 239-41.

15. Özyürek M. Changing the Attitudes towards the Handicapped. Ankara; Kök Publishing, 2006; 11-23.

16. Sargin N. A Study on the Attitudes of Teachers in terms of Preschool Children with Mental Disabilities. XI. National Education Congress Papers, Konya: Education Publications, 2002.

17. Sarı HY, Bektaş M, Altıparmak S. Determination of the Attitudes of Nursing Students towards the Handicapped. New Medicine Journal, 2010; 27: 80-83.

18. Sümbül AM, Sargın N. Analysis of the Attitudes of Teachers towards Preschool Inclusive Programs (in terms of various variables). XII. National Special Education Congress, Methods-Approaches-Strategies, Ankara University Faculty of Education Sciences Publications, 2002; (193): 225-243.

19. Şahin F, Güldenoğlu Bİ. The Effect of Training Programs about the Handicapped on Attitudes towards the Handicapped. Amasya University Journal of Education Faculty, 2013; 2 (1): 214-239.

20. Şenel HG. A Comparison of People who have Handicapped Siblings and who do not in terms of their Attitudes towards being Handicapped and their Levels of Anxiety. Journal of Special Education, 1995; 2: 33-9. 
21. T. C. Prime Ministry Department of the Administration of the Disabled, How does the Society Understand Being Disabled? Ankara, 2008.

22. Tervo RC, Azuma S, Palmer G, Redinius P. Medical students' attitudes toward persons with disability: a comparative study. Archives of Physical Medicine and Rehabilitation, 2002; 83: 1537-42.
23. Ünal C. A Research on the Psychology of General Attitudes or Values. AÜDTCF Publications, Ankara, 1981.

24. World Health Organization. International Classification of Impairment, Disabilities and Handicaps. 1980. 